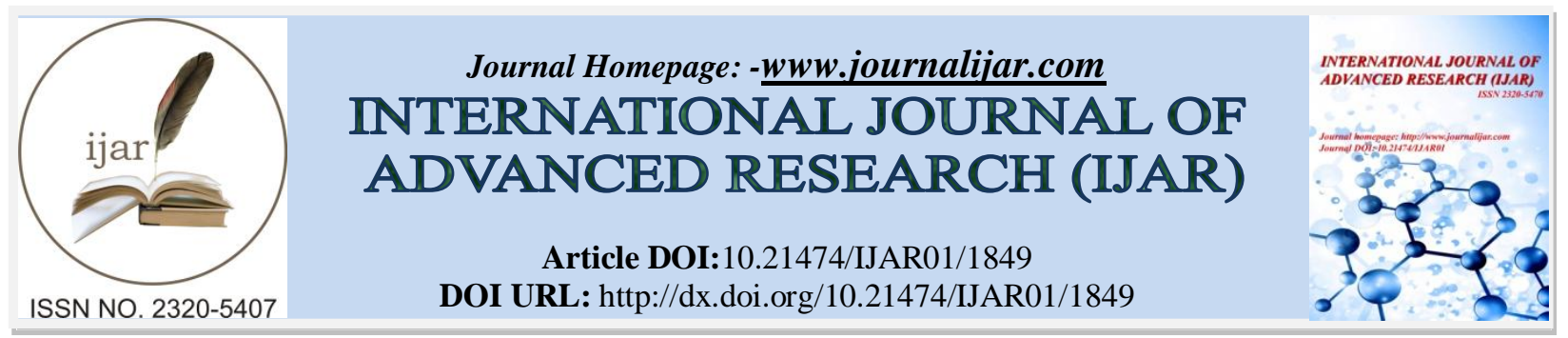

RESEARCH ARTICLE

\title{
ASSESSMENT OF INDUSTRIAL WASTEWATER POLLUTION IN DEVELOPING COUNTRIES - CURRENT POLLUTION LEVEL IN RWANDA.
}

\author{
Sosthene Mubera*, Philip Ochieng Ogada and Dragan Cigoja.
}

UNEP-Tongji Institute of Environment for sustainable development. College of Environmental Science and Engineering. 20092, China.

\section{Manuscript Info}

Manuscript History

Received: 12 August 2016

Final Accepted: 16 September 2016

Published: October 2016

Key words:-

Rwanda, Industrial wastewater,

Biochemical oxygen demand (BOD),

Chemical oxygen demand (COD),

Nitrates $\left(\mathrm{NO}_{3}{ }^{-}\right)$, Phosphates $\left(\mathrm{PO}_{4}{ }^{3-}\right)$,

Rwanda Bureau of Standards (RBS).

\section{Abstract}

In both developed and developing countries, wastewater treatment has been a serious matter on small and large scale. Created industries, enterprises and factories manufacturingfinal products from raw materials use fresh water in their processeswhich result in wastewater heavily loaded with various pollutants. Pollution level depends on the type of factory or industry. Although some industries /factories date from nineties (90s), Industrial sector is quite new in Rwanda.Industrial reforms started early 2000 with Rwanda vision 2020 launch where by 2020 , industrial and service sector will contribute about $42 \%$ of country's GDP. BOD, COD, Nitrates and phosphates were measured, Analyzed and show that Horizon Sopirwa, AMEKI color, UTEXRWA and Nyanza dairy have the highest concentration in Nitrate, Phosphate, BOD and COD respectively. Results found that at least each factory/industry has surpassed Rwanda Bureau of Standards' effluent limits given on the appendix. Pretreatment and further analyses have been recommended in order to deepen Rwanda's water pollution understandings and taking environmental pollution prevention measures.

Copy Right, IJAR, 2016,. All rights reserved.

\section{Introduction:-}

A wastewater treatment plant (WWTP) plays a significant role in protection of the environment; it filters harmful pollutants to the environment and properly disposes them. Treatment technologies vary from type of wastewater; whether it is domestic wastewater, agriculture wastewater, Municipal wastewater or industrial wastewater. Wastewater contains plant nutrients, pathogenicmicroorganisms, heavy metals organic pollutants and biodegradable organics. Micro-pollutants can cause health and environmental problems and also have economic/financial impacts when untreated wastewater is released into the environment [1].

In developed countries, integrated water management presents accessibility of domestic, urban and industries facilities connected to water supply pipes and sewer pipes flowing wastewater in treatment plants where wastewater passes through number of treatment stages before effluent in the environment. Industrial wastewater treatment bloomed since 1990s when countries realized an increase of pollution percentage in cities and more investment being made in industrial sector. Modern countries have developed wastewater management practice to minimize high loading in treatment plant, this is done by grit screening, pretreatment and/or sewer discharge separation [2].

Corresponding Author:-Sosthene Mubera. 
On the other hand in developing countries; industries are increasing countries' GDP and creation of new jobs but no appropriate sanitation goes with this economic growth. Implementation of standards must go in parallel with development in environmental agencies for monitoring, controlling, regulating to enhance good water quality and non-fresh water stress which is being observed and leading to waterborne illnesses. In addition; industries may not want to treat their discharges because of high operational costs and big amount of energyuse to treat wastewater resulted fromdifferent types of processing of industries [3].

Table 1:- Industrial wastewater-types amount and effects: Water pollutants by Industrial sector [4].

\begin{tabular}{|l|l|}
\hline Sector & Pollutant \\
\hline Chemicals & COD, Organic chemicals, heavy metals, SS, and cyanide \\
\hline Mining & SS,metals, acid and salts \\
\hline Textile and leather & BOD,Solids,sulfates and Chromium \\
\hline Pulp and paper & BOD,COD,Solids,chlorinated organic compounds \\
\hline Petrochemicals and refineries & BOD,COD,Mineral oils, phenols and chromium \\
\hline Iron and steel & BOD,COD, oil, metals, acids,phenols and cyanide \\
\hline Microelectronics & COD and organic chemicals \\
\hline
\end{tabular}

Industries play big roles in African economy; the largest parts of industrial firms are small or micro enterprises operating in cooperation with foreign (developed) countries. These resource dependent economies account for over 60 per cent the continent's total GDP, with the combined GDP of largest economies (Nigeria \& South Africa) [5] on the continent. Industrial development implies opportunities for employment growth, country's population wellbeing grows and urbanization takes place in all sectors[6]. The agriculture and manufacturing sectors are the most present sectors in many African countries. Focus is put in agriculture, manufacturing, transport and development of infrastructures which consume and discharge much water during processing. Most of the water divert for human use as in irrigation and an increasing demand due to agricultural and industrial production undelay water stress in many African regions. During years of African industrial development; problems with sanitation have arisen, factories and industries discharge illegally polluted wastewater in the fresh water bodies and therefore cause diseases [7].

Like everywhere, industrial sector became a great but challenging opportunity for Rwanda and its environment.Industriesextract fresh water upstream in surrounding water bodies and discharge water at downstream of the same water body. Water is the single largest factor in goods production for Rwanda. It is used in different sectors including agriculture, water supply, home facility, commerce, and industries. After production processes, water is discharged as wastewater where it reaches the environment containing a given amount of nutrients, chemicals, heavy metals, and organic matters which are usually higher than Rwanda bureau of standards (RBS) effluent limits [8]

The aim of the present paper work is to analyze the pollution level of organic matter in effluent wastewater from considerable factories and facilities in Rwanda.

\section{Materials and Methods:-}

Nitrate Determination:-

Nitrate concentration in wastewater can be determined based on the diazotization of sulfanilic acid by the available nitrite and subsequent coupling with an agent such as $\alpha$-Naphtylamine $(\alpha=1,2,3)$. Using $\mathrm{N}$-(1-naphthyl)ethylenediaminedihydrocloride presents an advantage of color development time reduction to 2 minutes while the coupling of diazotized sulfanilic acid with $\alpha$-naphtylamine takes from 10 to 30 minutes for full color development and with $\alpha$-naphtylamine acetate ;the color development takes 30 minutes([9]. During the test, a filtered sample is passed through a column containing granulated copper-cadmium in order to reduce nitrate to nitrite. At this stage, the nitrite is determined by diazotizing with sulfanilamide and coupling with $\mathrm{N}$-(1-naphthyl)-ethylenediamine hydrochloride to form a highly colored azo dye which is determined colorimetrically. The intensity of coloration is referred to the concentration of the available nitrites ion present in samples. The range of dosage is $0.05-10 \mathrm{mg} / \mathrm{L}$ nitrate-nitrite nitrogen[10], 


\section{Phosphorus determination:}

Ammonium molybdate and potassium antimonyl tartrate react in acid medium with orthophosphate to form a heteropolyacid that is reduced to intensely colored molybdenum blue by ascorbic acid [11].

$\mathrm{PO}_{4}^{3-}+12 \mathrm{M}_{0} \mathrm{O}_{4}^{2+}+24 \mathrm{H}^{+} \rightarrow \mathrm{H}_{3} \mathrm{PO}_{4}\left(\mathrm{M}_{\mathrm{o}} \mathrm{O}_{3}\right)_{12}+12 \mathrm{H}_{2} \mathrm{O}$ ( Phosphomolybdic acid) (1)

$\mathrm{H}_{3} \mathrm{PO}_{4}\left(\mathrm{M}_{\mathrm{o}} \mathrm{O}_{3}\right)_{12} \stackrel{\mathrm{sb}}{\longrightarrow} \mathrm{PSb}_{2} \mathrm{Mo}_{12} \mathrm{O}_{40}^{3-}$ (Phosphomolybdenum blue)

There is a direct relationship between the intensity of the color of a solution and the concentration of the colored component which it contains. In some cases it is easy to determine the concentration of a sample based on its color intensity by comparing its color with those of a series of solutions of known concentration of the analyte species.In other cases, by UV spectrophotometer, the amount of electromagnetic radiation in the visible region of the spectrum absorbed by a colored solution is often directly proportional to the concentration of the colored species as defined by the Beer-Lambert Law $(\mathrm{A}=\varepsilon \mathrm{cl})$. During test ; a beam of light of intensity Io is focused on a sample, and a portion, $\mathbf{I}$, is absorbed by the analyte species.

To mathematically express the spectrometer measurement, we use Beer-Lambert Law [12];

$\mathrm{A}=\log \left(\mathrm{I}_{\mathrm{o}} / \mathrm{I}\right)$

$\mathbf{A}=\varepsilon \mathrm{cl}$

Thus, the absorbance of a solution is directly proportional to its concentration ( $\mathbf{c}$ ), as long as the solution path length (1). Phosphate reacts with ammonium molybdate in the presence of suitable reducing agents to form a blue colored complex, the intensity of which is directly proportional to the concentration of phosphate in the solution. The phosphate content of the wastewater sample is obtained by first plotting the absorbance of a series of standard solutions against the corresponding concentrations, thus giving a calibration curve. The concentration of phosphate in the unknown sample is thenbe determined from the graph[13].

\section{Biochemical Oxygen Demand (BOD):}

Biochemical Oxygen Demand for 5 days $\left(\mathrm{BOD}_{5}\right)$ is a chemical procedure for determining the amount of dissolved oxygen required by biological organisms to degrade organic matter present in a body of water under a certain temperature over 5 days [14]. After sampling wastewater, different steps in $\mathrm{BOD}_{5}$ test were done in laboratory and the $\mathrm{BOD}_{5}$ of wastewater was calculated using equation [15].

BOD $\left(\frac{m g}{l}\right)=\frac{D 1-D 2}{p}(5)$

Where:

D1 = dissolved oxygen of diluted sample immediately after dilution $(\mathrm{mg} / \mathrm{L})$

$\mathrm{D} 2=$ dissolved oxygen of diluted sample after 5-day incubation at $20^{\circ} \mathrm{C}(\mathrm{mg} / \mathrm{L})$

$\mathrm{P}=$ fraction of wastewater sample volume to total combined volume.

\section{Chemical Oxygen Demand (COD):}

Like BOD, COD is most important water quality parameter where analysis measures the reduction of the strong oxidant potassium dichromate $(\mathrm{KCr} 2 \mathrm{O} 7)$ under highly acidic conditions at high temperature, and then correlates this reaction to standards with known levels of oxygen demand. After the digestion, the orange color persists because of $\mathrm{K}_{2} \mathrm{Cr}_{2} \mathrm{O}_{7}$ is not reduced and its determination by colorimetric method permits to evaluate the quantity of $\mathrm{K}_{2} \mathrm{Cr}_{2} \mathrm{O}_{7}$ consumed by oxidable matters of sample and this is expressed in terms of equivalent oxygen. Wastewater samples are diluted and added to both the standard and miniaturized COD ampules. COD samples arethen incubated at $1500 \mathrm{C}$ for $2 \mathrm{~h}$ in a dry incubator. The color intensification (green color) is proportional to the organic matter which is also proportional to the COD measured by spectrophotometer at the wavelength of $600 \mathrm{~nm}$.data are plotted using Microsoft excel [16].

\section{Calibration curves:-}

A calibration is the process of establishing a relationship between two properties. In the case of colorimetric measurement, a calibration curve establishes a relationship between a sample's concentration and the amount of light it absorbs, which is a measurement of color intensity. Concentration is plotted versus absorbance and this linear relationship in a colorimetric measurement is known as Beer's Law which state that[17] 
$\mathrm{A}=\mathrm{abC}(6)$

(A: measured absorbance, a:molar extinction coefficient (constant),b:path length of sample cell C:Concentration ) A linear calibration has the mathematical relationship: $y=m x+b$, where $y$ is the concentration, $m$ is the slope of the line, $\mathrm{x}$ is the measured absorbance, and $\mathrm{b}$ is the intercept. But chemistry is very complex and sometimes it depends on the relationship between absorbance and concentration and may be nonlinear [18].

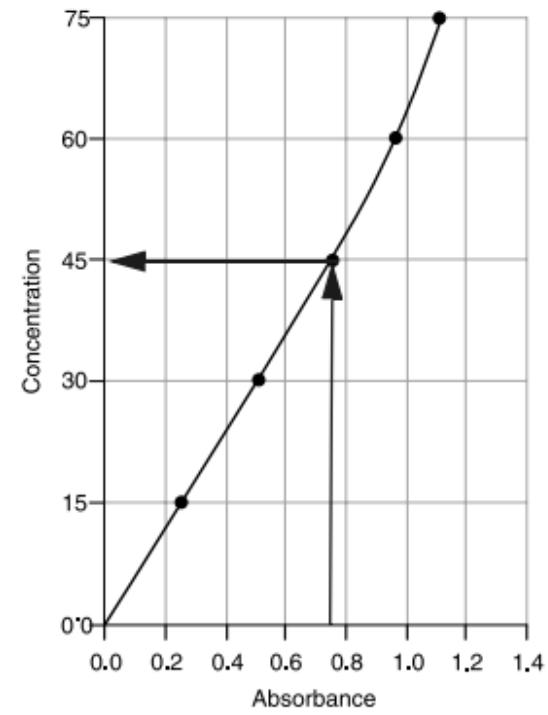

Figure 3:-Absorbance and concentration calibration curve

Plotting nutrients concentration in nutrient solution curve form of simple spectrophotometric techniques is presented in curves. Most likely nitrate and phosphate are suitable and most used for these techniques. Together with example of standard calibration curves obtained in laboratory, actual nutrient concentration are plotted, compared with standards curves and values determined. One of advantages is that these protocols enable the routine and sensitive measurements of nutrient solution composition requiring only a spectrophotometer and minimal use of other basic laboratory equipment [19].

\section{Results and Discussion:- \\ Nitrate and Phosphate:-}

The maximum tolerance limit of nitrate concentrations from industrial wastewater to be discharged in the environment is $20 \mathrm{mg} / \mathrm{L}$. Resultsshow that the concentration levels of nitrates for Nyanza dairy plant and Horizon Sopirwaare relatively higher than the tolerance limit of industrial waste water discharged. Phosphate which is not toxic and have no restriction on human health or bring other organisms directly, but it has indirectly serious threat to water qualityand is considered harmful because of its impact in rapid growth of aquatic plants such as algae. Highest phosphate concentration than RBS tolerance limits is observed in BMC SKOL, Masaka Dairy, Ameki color, Nyanza dairy plant and Kinazi cassava plant.

Figure 4:- Nitrates and Phosphates values in effluent wastewater.

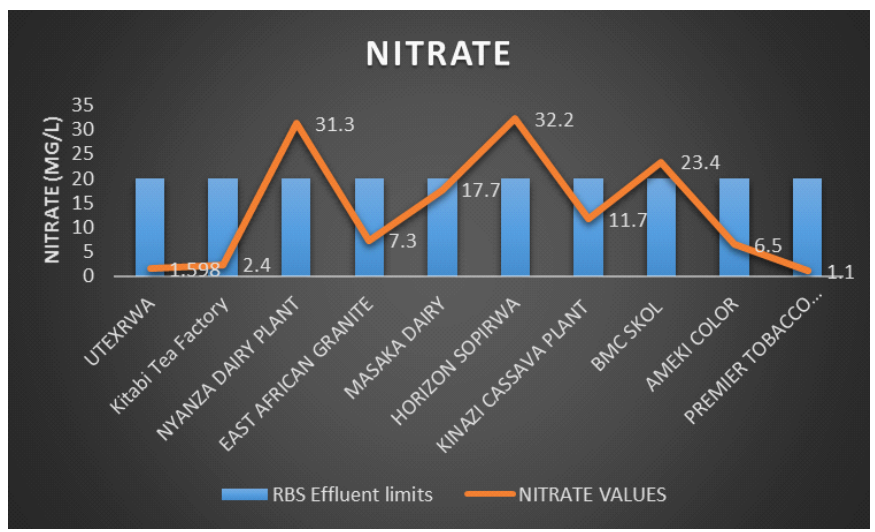




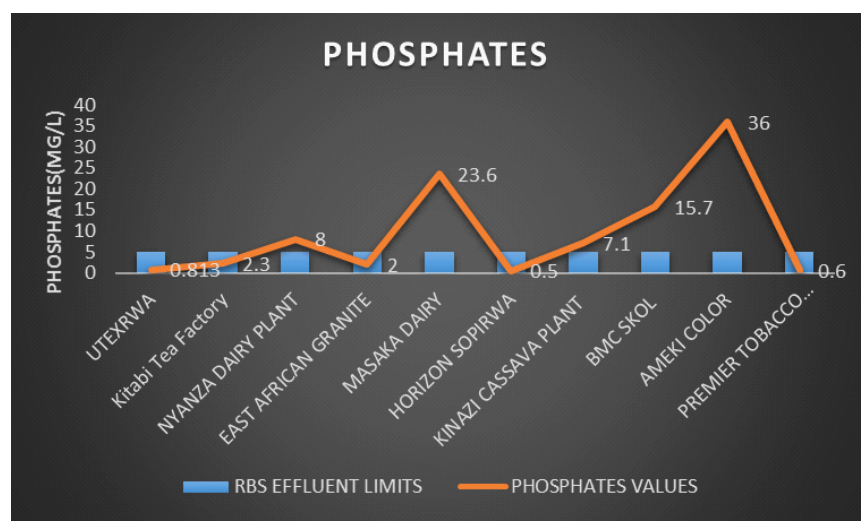

\section{Biochemical oxygen demand and carbon oxygen demand}

All industries and facilities have BOD values which arehigherthan RBS tolerance limit (50mg/l). These high values of BOD are due to high concentration of organic pollutants from daily activities. After being discharged in surrounding water bodies, such polluted water have a negative impact to the environment because it will reduce oxygen level in water by accelerating bacterial growth in the river which diminish the presence of most fish and many aquatic ecosystems. Like BOD, Chemical oxygen demand (COD) inert organic matter, and shows the oxygen required to oxidize all organic material into carbon dioxide and water. Only Premier Tobacco company and Masaka Dairy are below RBS standards with $228 \mathrm{mg} / \mathrm{L}$ and $223 \mathrm{mg} / \mathrm{L}$ respectively. Others are discharge high polluted wastewater in terms of COD.

Figure 5:-BOD5 and COD values in Effluent wastewater.
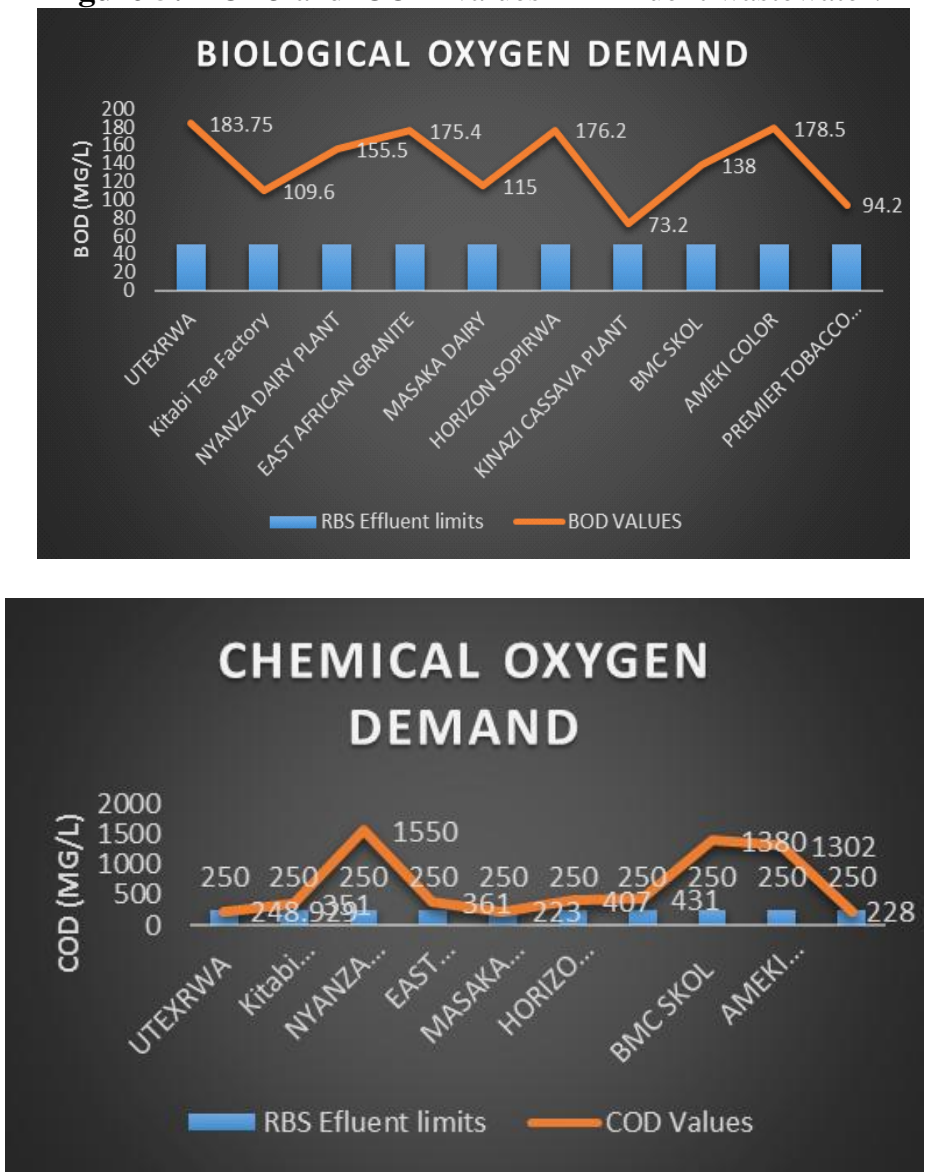
The pollution level of sampled zones shows that pollution will considerably increase if nothing is done to pretreat water before entering neighborhood water bodies. Results of samples from considered factories/industries shows that $30 \%$ have surpassed nitrate effluentlimits, 50\% surpassed phosphates effluent limits, $80 \%$ surpassed COD effluent limits and 100\% surpassed BOD effluent limits. This may cause severe water quality problems. Phosphate and nitrates will promote excessive growth of algae and other aquatic plants, as the algae and other aquatic plants die and decompose high levels of organic matter and the decomposing organisms deplete the water of available oxygen, causing the death of other organisms, such as fish. High COD and BOD levels decrease the amount of dissolved oxygen available for aquatic organisms. Low dissolved oxygen reduces cell functioning, disrupts circulatory fluid balance in aquatic spices. This result in individual organisms' death, releasing diseases to the community and creating unsafe water supply sources.

\section{Conclusions and some Recommendations:-}

Industrial sector plays a major role in pollution of the environment. Highest concentration depends on the type of the raw material. Among Rwandan industries'wastewater discharge; highest values are observed at Horizon Sopirwawith high Nitrate concentration $(32.2 \mathrm{mg} / \mathrm{L})$, AMEKI color with highest phosphate concentration $(36 \mathrm{mg} / \mathrm{L})$, UTEXRWA with highest BOD concentration $(183.75 \mathrm{mg} / \mathrm{L})$ and Nyanza dairy with highest COD concentration $(1550 \mathrm{mg} / \mathrm{L})$.

Further studies on metal, $\mathrm{PH}$, turbidity are recommended for investigation of all improper wastewaterdischarge which continuously pollutes water, environment and disturbs the balance of ecosystem by killing various animals, plants and human in the surrounding environment. Pretreatment before effluent is highly recommended to reduce the amount of nutrients, chemicals, metals and other types of pollutants entering in the environment.

\section{References:-}

1. K. Gomes and I. Ebrary, "Wastewater management: A UN-Water Analytical Brief," UN Water, p. 55, 2009.

2. E. E. A. R. No, Effectiveness of urban wastewater treatment policies in selected countries: an EEA pilot study, no. 2. 2005.

3. M. Von Sperling, C. Augusto, and D. L. Chernicharo, "Urban wastewater treatment technologies and the implementation of discharge standards in developing countries," vol. 4, pp. 105-114, 2002.

4. H. Shi, "Industrial wastewater-types, amounts and effects," Point Sources Pollut. Local Eff. its Control, vol. I, pp. 1-6, 2002.

5. I. Nexus, O. Barriers, and S. Development, African Development Report 2015. 2015.

6. UNCTAD and UNIDO, Economic development in Africa report 2011: fostering industrial development in Africa in the new global environment, no. Special Issue. 2011.

7. EDWARD, "WATER: Africa," Living waters, vol. 45, no. 5, pp. 1-2, 2008.

8. F. D. Nzabuheraheza, J. H. Y. Katima, K. N. Njau, S. Kayombo, and N. A. Niyigena, "Wastewater Treatment for Pollution Control," vol. 1, no. 1, pp. 1-7, 2012.

9. M. B. Shinn, "Colorimetric Method for Determination of Nitrite," Ind. Eng. Chem. Anal. Ed., vol. 13, no. 1, pp. 33-35, 1941.

10. P. K. Tarafder and D. P. S. Rathore, "Spectrophotometric determination of nitrite in water," Analyst, vol. 113, no. 7, pp. 1073-1076, 1988.

11. I. A. Tsoulfanidis, G. Z. Tsogas, D. L. Giokas, and A. G. Vlessidis, "Design of a field flow system for the online spectrophotometric determination of phosphate, nitrite and nitrate in natural water and wastewater," Microchim. Acta, vol. 160, no. 4, pp. 461-469, 2008.

12. S. O. Sommerer, B. L. Law, and D. Calloway, "Titration Curve Analysis :," vol. 74, no. 7, pp. 1996-1998, 1997.

13. B. S. Gentle, P. S. Ellis, M. R. Grace, and I. D. McKelvie, "Flow analysis methods for the direct ultra-violet spectrophotometric measurement of nitrate and total nitrogen in freshwaters," Anal. Chim. Acta, vol. 704, no. 1, pp. 116-122, 2011.

14. B. Martin and C. C. Hach, "An Introduction to Standards and Quality Control for the Laboratory In memory of," no. 2426, 1919.

15. M. Best, “(19) United States (12),” vol. 1, no. 19, 2003.

16. T. M. Lapara, J. E. Alleman, and P. G. Pope, "Miniaturized closed $\mathrm{re}^{-}$ux , colorimetric method for the determination of chemical oxygen demand," vol. 20, pp. 295-298, 2000.

17. F. Swinehart, "The Beer-Lambert," vol. 39, no. 7, pp. 333-335, 1962. 
18. K. Michel, B. Bureau, C. Boussard-plédel, T. Jouan, J. L. Adam, K. Staubmann, and T. Baumann, "Monitoring of pollutant in waste water by infrared spectroscopy using chalcogenide glass optical fibers," vol. 101, pp. 252259, 2004.

19. E. Diatloff and Z. Rengel, "Compilation of Simple Spectrophotometric Techniques for the Determination of Elements in Nutrient Solutions," J. Plant Nutr., vol. 24, no. 1, pp. 75-86, 2001.

20. Adams, C. E., Donald, J. Ku, Joseph, B. A. łu L., Jerry, B. Ku, Robert, L. B. Ku, Don, D. B. Ku, ... Switzenbaum, S. ¡u M. S. (1999). Wastewater Treatment.

21. America, S. (2010). co, (4).

22. Bachmann, N. (2015). Sustainabla biogas production in municipal wastewater treatment plants, 20.

23. Bastian, R., Cuttica, J., Fillmore, L., Bruce, H., Hornback, C., Levy, D., \&Moskal, J. (2011). Opportunities for Combined Heat and Power at Wastewater Treatment Facilities : Market Analysis and Lessons from the Field Combined Heat and Power Partnership. US EPA, CHP Partnership, (October), 57. http://doi.org/430R11018

24. Benedict, T. (2013). PATHWAYS FOR PROMOTING ANAEROBIC DIGESTION IN WASHINGTON STATE An Analysis of Benefits and Production Capacity with Recommendations for Advancement, (September).

25. CastelletViciano, L., Molinos-Senante, M., Hernández Chover, V., \& Hernandez-Sancho, F. (n.d.). Efficiency Assessment of Wastewater Treatment Plants: a Data Envelopment Analysis Approach Integrating Technical, Economical and Environmental Issues.

26. Rasekh, A., Hassanzadeh, A., Mulchandani, S., Modi, S., \& Banks, M. K. (2016). Smart Water Networks and Cyber Security. Journal of Water Resources Planning and Management, 77843(7), 01816004. http://doi.org/10.1061/(ASCE)WR.1943-5452.0000646

27. Ravindranath, N. H., \&Balachandra, P. (2009). Sustainable bioenergy for India: Technical, economic and policy analysis. Energy, 34(8), 1003-1013. http://doi.org/10.1016/j.energy.2008.12.012

28. Santos, I. F. S. dos, Barros, R. M., \& Tiago Filho, G. L. (2015). Electricity generation from biogas of anaerobic wastewater treatment plants in Brazil: An assessment of feasibility and potential. Journal of Cleaner Production, 126, 504-514. http://doi.org/10.1016/j.jclepro.2016.03.072

29. Schwarzenbeck, N., Bomball, E., \& Pfeiffer, W. (2008). Can a wastewater treatment plant be a powerplant? A case study. http://doi.org/10.2166/wst.2008.215

\section{Supporting Information:-}

APPENDIX A. Rwanda bureau of standards Industrial wastewater Effluent limits

\begin{tabular}{|l|l|l|}
\hline Determinants & Units & Upper limit and ranges \\
\hline Temperature increase & ${ }^{\circ} \mathrm{C}$ & 3 (variation) \\
\hline $\mathrm{pH}$ & & $6.0-9.0$ \\
\hline Dissolved Oxygen (min.) & $\%$ sat. & 60 \\
\hline $\mathrm{BOD}_{5}$ (max.) & $\mathrm{mg} / \mathrm{a} 20^{\circ} \mathrm{C}$ & 50 \\
\hline $\mathrm{COD}(\mathrm{max})$ & $\mathrm{mg} / \mathrm{l}$ & 250 \\
\hline Oil and grease & $\mathrm{Mg} / \mathrm{l}$ & 10 \\
\hline Colour & $\mathrm{TCU}$ & 50 \\
\hline Turbidity & $\mathrm{NTU}$ & 30 \\
\hline Total dissolved solids (TDS) & $\mathrm{mg} / \mathrm{3}$ & 2000 \\
\hline Total suspended solids(TSS) & $\mathrm{mg} / \mathrm{5} / 100 \mathrm{ml}$ & 50 \\
\hline Faecal coliform & Counts & 1000 \\
\hline Coliforms & Number/100ml & 400 \\
\hline
\end{tabular}




\begin{tabular}{|l|l|}
\hline Determinants in $\mathbf{~ m g / l}$ & Upper limit and ranges \\
\hline Free and saline ammonia (as N) & 50 \\
\hline Ortho phosphate (as P) or soluble phosphate & 1.5 \\
\hline Phenol & 2.0 \\
\hline Calcium as Ca & 500 \\
\hline Chloride as Cl & 600 \\
\hline Chlorine residual & 1 \\
\hline Fluoride as F & 1.5 \\
\hline Potassium as K & 100 \\
\hline Sodium as Na & 400 \\
\hline Sulphate as SO4 & 400 \\
\hline Sulphide & 1.0 \\
\hline Zinc as Zn & 5.0 \\
\hline
\end{tabular}

\begin{tabular}{|l|l|}
\hline Determinants in $\mathrm{mg} /$, unless otherwise stated & Upper limit and ranges \\
\hline Arsenic as $\mathrm{A}$ & 0.01 \\
\hline Benzine $\mathrm{mg} / \mathrm{l}$ & 0.00 \\
\hline Boron as $\mathrm{B}$ & 0.5 \\
\hline Cadmium as $\mathrm{Cd}$ & 0.01 \\
\hline Chromium total $(\mathrm{Cr})$ & 0.05 \\
\hline Chromium as $\mathrm{Cr}$ (total) & 0.5 \\
\hline Cobalt as $\mathrm{Co}$ & 1 \\
\hline Copper as $\mathrm{Cu}$ & 3 \\
\hline Cyanide as $\mathrm{CN}$ & 0.1 \\
\hline Iron as $\mathrm{Fe}$ & 3.5 \\
\hline Lead as $\mathrm{Pb}$ & 0.1 \\
\hline Manganese as Mn & 0.1 \\
\hline Mercury as $\mathrm{Hg}$ (total) & 0.002 \\
\hline Nickel as $\mathrm{Ni}$ & 2 \\
\hline Selenium as Se & 0.02 \\
\hline
\end{tabular}

